Volume 2 Issue 2, July-December 2021: pp.113-122.

Faculty of Law, Universitas Lampung, Bandar Lampung, Indonesia. http://jurnal.fh.unila.ac.id/index.php/ip

P-ISSN: 2723-2638 E-ISSN: 2745-9314

\title{
The Effort to Reduce Over Capacity in Correctional Facilities through Social Work Alternative Punishment
}

\author{
Maiza Putri \\ Universitas Lampung, Indonesia \\ Maiza.peca@gmail.com
}

Submitted: Jan 14, 2021; Reviewed: Jan 27, 2021; Accepted: Apr 23, 2021

Article's Information
keywords:
Alternative Criminal; Overcapacity;
Policy Formulation.

DOI :

https://doi.org/10.25041/ip.v2i2.2217
Overcapacity in prisons usually happens due to the high number of incoming inmates which is not directly proportional to the capacity of the correctional institution. It is a problem in realizing the aim of both the correctional system and the criminal justice system and raises the urgency of alternative penalties application. This research aims twofold: First, to uncover the causes of prison overcapacity, Second, to elaborate on how policy is being developed toward alternative punishment to reduce overcapacity. This study takes a normative and empirical legal approach, with data gathered through literature reviews and field studies. In conclusion, it would appear that alternative punishments are essential to change the negative views regarding the application of criminal sanctions in prison into the application of alternative criminal sanctions for social work that have a positive impact. The punishment that can be used as an alternative to imprisonment is the social work penalty. The social work penalty is considered to reduce the negative impact on the implementation of imprisonment in prisons that experience overcapacity. This research suggests that the social work criminal formulation policy should be immediately formulated in the Draft of Criminal Code (RUU KUHP). 


\section{A. Introduction}

Criminalization is a phenomenon that often attracts public attention. This is because punishment is a benchmark for justice and criminal law enforcement. ${ }^{1}$ Deprivation of freedom from imprisonment and confinement is still a tradition to achieve a deterrent effect and general prevention for perpetrators. ${ }^{2}$ The term criminal is often equated with punishment, which distinguishes criminal law from other laws. Many experts express opinions about the definition of a criminal. Sudarto expressed an opinion about the meaning of criminal in his book, namely punishment or misery imposed on someone who violates or fights against provisions in the form of laws regulated by the State, intentionally inflicted as misery. ${ }^{3}$ Roeslan Saleh defines crime as a response to offenses that are often in the form of misery deliberately inflicted by the State on the perpetrators of the offense. Roeslan Saleh also stated that sorrow is not the ultimate aspired goal. ${ }^{4}$ Even the arbitrary use of authority by police officers also triggers riots and creates social movements that lead to socio-political debates. ${ }^{5}$

Actions with imprisonment are restrictions on movement in a correctional institution given to a convict by requiring the convict to comply with the rules and regulations determined by a correctional institution. ${ }^{6}$ The placement of convicts to serve sentences is based on court decisions that have permanent legal force, which aims to make the convicts aware of their mistakes and fostered to meet their needs and be accepted back in the community. ${ }^{7}$ The theoretical assumptions about the role in regulation and public discourse in policy change, where the pretrial application in the United States of America is stopped or severely restricted. ${ }^{8}$ Therefore, policies related to the sentencing process need to be appropriately handled under the existing capacity because these are common types of behavior that legal policymakers must try to regulate. ${ }^{9}$

Factors that make the crime rate in a society increasingly soar, namely economic factors and technological factors. ${ }^{10}$ To overcome crimes against various means as a reaction that can be given to criminals in criminal and non-criminal means can be integrated. However, suppose illegal means are called upon to tackle crime. In that case, it means that criminal law politics will be carried out, namely holding elections to achieve the results of criminal legislation following the various needs that exist in society. Correctional Institutions or Lembaga Permasyarakatan (Lapas) have a strategic function in realizing the criminal justice system's goals, namely so that prisoners can integrate healthily with the community so that they can play a role again as free and responsible members of society. To realize this goal, preparation is needed, both regarding facilities, personnel, management, and the rules.

\footnotetext{
${ }^{1}$ Rugun Romaida Hutabarat, "Problematika Lembaga Pemasyarakatan Dalam Sistem Peradilan Terpadu," Jurnal Muara Ilmu Sosial, Humaniora, Dan Seni 1, no. 1 (May 10, 2017): 42, https://doi.org/10.24912/jmishumsen.v1i1.333.

2 Usman Usman, Bahder Johan Nasution, and Elizabeth Seregar, "Over Kapasitas Lembaga Pemasyarakatan Dalam Perespektif Kebijakan Hukum Pidana,” Wajah Hukum 4, no. 2 (October 19, 2020): 43644, https://doi.org/10.33087/WJH.V4I2.256.

${ }^{3}$ Sudarto, Kapita Selekta Hukum Pidana (Bandung: Alumni, 1986): 109.

${ }^{4}$ Roeslan Saleh, Stelsel Pidana Indonesia (Jakarta: Aksara Baru, 1983): 9.

5 Kiana Alikhademi et al., "A Review of Predictive Policing from the Perspective of Fairness," Artificial Intelligence and Law, April 15, 2021, 1-17, https://doi.org/10.1007/s10506-021-09286-4.

${ }^{6}$ P.A.F. Lamintang, Hukum Penitensier Indonesia (Bandung: Armico, 1984): 69.

${ }^{7}$ Dwijaya Priyatno, Sistem Peradilan Pidana Penjara (Bandung: Rafika Aditya, 1996): 7.

${ }^{8}$ Pascal D König and Georg Wenzelburger, "When Politicization Stops Algorithms in Criminal Justice," The British Journal of Criminology 61, no. 3 (April 24, 2021): 832-51, https://doi.org/10.1093/bjc/azaa099.

${ }^{9}$ Shahar Ayal, "Comments on 'the Law of Good People': Regulating Justified Dishonesty," Jerusalem Review of Legal Studies 22, no. 1 (December 1, 2020): 38-48, https://doi.org/10.1093/jrls/jlz013.

10 Galih Puji Mulyono and Barda Nawawi Arief, "Upaya Mengurangi Kepadatan Narapidana Dalam Lembaga Pemasyarakatan Di Indonesia," Law Reform 12, no. 1 (March 31, 2016): 1, https://doi.org/10.14710/lr.v12i1.15838.
} 
The fact is that correctional institutions are still faced with various limitations. In fostering prisoners, there are many obstacles so that the goals to be achieved are less than optimal and even lead to the failure of the function of a correctional institution. ${ }^{11}$ Police institutions must consider the challenges faced by law enforcement agencies themselves with the procedurally fair treatment of individuals. ${ }^{12}$ Excess occupancy or overcapacity is one of the most obvious problems faced by correctional institutions in Indonesia in fostering prisoners. ${ }^{13}$ The phenomenon mentioned above is not a conducive factor for fostering prisoners, including social reintegration and being able to be re-accepted by the community and able to carry out their roles as other members of the community. ${ }^{14}$

Economic factors and technological factors are the causes of crime rates in the community soaring up. In the coaching process, prisoners have many obstacles; overcapacity becomes a real problem in the coaching process. It can be less than optimal, and there will even be malfunctions in a correctional institution. ${ }^{15}$ Overcapacity is caused by the unbalanced housing growth rate for residential facilities and the increasing number of new housing inputs, which are far from the disproportionate outputs of those who have completed their detention period. Paradigms and laws that apply in Indonesia are also a factor in overcapacity in prisons in Indonesia. The cases that most support overcrowding in prisons are cases of drugs, theft, and violence against children. Overcapacity tends to have negative implications for several things, including the low level of security/supervision.

Criminal law policy is the activity of formulating criminal law that meets the requirements of justice and usability for the present and the future. However, along with the development of society, not every criminal policy can always carry out this mission. In relation to the overcapacity of prisons, it is impossible to separate this from a criminal law policy that is out of step with prison capacity. At the policy formulation stage, when there is more criminalization, the more acts that are threatened with criminality, and when the type of crime that is chosen to be threatened for violating the norms of criminal law is imprisonment, the consequence is that more and more violations of criminal law are threatened with imprisonment. Therefore, when there is a violation of these norms at the application stage, prosecutors and judges will apply the threat of imprisonment.

Lack of state supervision of correctional institutions such as a minimal budget, planning system, aspects of criminal law policies is additional records of problems in a correctional institution. ${ }^{16}$ The impact of the ineffective use of the criminal deprivation of prison freedom is, of course, very contrary to the developments currently sweeping the international community, which seeks to minimize the imposition of imprisonment by implementing selective and limiting policies that have a more positive impact. For this reason, a formulation policy through social work is needed to overcome these efforts. Policy formulation is the initial stage and

11 Rocky Marbun, "Konsep Diyat Sebagai Alternatif Pemidanaan Dalam Sistem Peradilan Pidana Untuk Mengatasi Fenomena Overcapacity Lembaga Pemasyarakatan," Jurnal Hukum Dan Peradilan 6, no. 2 (July 31, 2017): 189, https://doi.org/10.25216/jhp.6.2.2017.189-212.

12 Weston J. Morrow, Samuel G. Vickovic, and John A. Shjarback, "Motivation to Enter the Police Profession in the Post-Ferguson Era: An Exploratory Analysis of Procedural Justice,” Criminal Justice Studies 34, no. 2 (2021): 135-55, https://doi.org/10.1080/1478601X.2020.1802591.

13 Ilham Panunggal Jati, "Implikasi Overcapacity Terhadap Lembaga Pemasyarakatan Di Indonesia," Cepalo 3, no. 2 (November 25, 2019): 77, https://doi.org/10.25041/cepalo.v3no2.1847.

14 Safaruddin Harefa, "Kebijakan Kriminal Dalam Menanggulangi Kelebihan Kapasitas Lembaga Pemasyarakatan,” Jurnal Yuridis 5, no. 2 (April 26, 2019): 294, https://doi.org/10.35586/.v5i2.773.

15 I Wayan Putu Sucana Aryana, "Efektivitas Pidana Penjara Dalam Membina Narapidana," DiH: Jurnal Ilmu Hukum 11, no. 21 (October 1, 2015): 39-44, https://doi.org/10.30996/dih.v11i21.446.

16 Angkasa Angkasa, "Pidana Perampasan Kemerdekaan Mandiri Sebagai Jenis Pidana Alternatif Untuk Mengurangi Kelebihan Populasi (Overpolulation) Narapidana Di Lembaga Pemasyarakatan Dan Beban Pemerintah," Perspektif Hukum 20, no. 2 (September 12, 2020): 1-30, https://doi.org/10.30649/PHJ.V20I2.268. 
source of foundation in the concretization process for further criminal law enforcement, namely the application and execution stages.

Based on the Correctional Database System or Sistem Database Pemasyarakatan (SDP) from 2014 to 2019, the number of prisoners in Class I Penitentiary Bandar Lampung has experienced an overcapacity of $80 \%$. Referring to the data obtained above, correctional institutions in the province of Lampung are a category of correctional institutions that must receive attention regarding excess occupancy or over capacity. Therefore the authors described above, the authors are interested in studying more deeply "Efforts to Reduce over Capacity in Correctional Institutions through Crime Alternative Social Work". The problem of overcapacity in prisons is a legal issue that has not yet been resolved. Therefore, systematic and comprehensive efforts are needed to overcome these problems, both in terms of policy and at the level of implementation. Based on this, the main problem in this research is how the formulation of alternative criminal policies to reduce overcapacity is, and how is the alternative criminal potential to implement prison sanctions in Indonesia? This study uses a normative juridical approach and an empirical juridical approach, where normative juridical research is legal research that puts the law as a building system of norms.

Meanwhile, empirical juridical research is carried out through direct data collection by conducting interviews. The data used in the form of primary data and secondary data. Methods of data collection using literature studies and field studies. The data analysis used is qualitative.

\section{B. Discussion}

\section{Policy Formulation of Alternative Punishments as an Effort to Reduce Correctional Institution Overcapacity}

Criminal law in Indonesia is not optimal, starting from the concept of law or legislation that does not touch what has become the ideals and goals of this nation's law. A sense of justice is interpreted by the concept of law regulated by the State that provides satisfaction with a sense of justice for all parties, especially for those who conflict with the law. The nature of the law should refer to justice, justice must be shaped and addressed by the rule of law, but in its implementation, the law sometimes tends to be forced to make decisions that feel far from a sense of justice. The law enforcement officers' concept of law is law formation, which is also one of the fundamental indicators concerning legal effectiveness.

Various efforts to enforce legal regulations that have justice for law enforcement officers need to be reviewed by every law enforcement agency to create integrity, credibility, and transparency. ${ }^{17}$ Rather than that, the implementation of the provisions of applicable regulations and the behavior of law enforcement officers and the community's behavior is also, of course, very much needed to form a sense of security and justice in the community. Indonesian people tend to interpret the law as an officer or law enforcement officer, so it creates an impact in the form of good and evil, which is always associated with the behavior of law enforcement officers. Public awareness in obeying legal regulations is crucial in creating law enforcement from a community perspective. Without a sense of trust, there will be no proper behavior of law enforcement officers if the community still finds many doubts about law enforcement officers in the process of a trial.

Imprisonment is one form of threat threatened with the main criminal in the law, which law enforcement officers often give to perpetrators of criminal acts that aim to correct a violator of rules or legal norms. ${ }^{18}$ Although the system of treating lawbreakers is heading towards a

\footnotetext{
17 July Esther, Bintang Me Naibaho, and Bintang Christine, "Mediasi Penal Dalam Penanganan Pelaku Tindak Pidana Sebagai Upaya Meminimalisir Kelebihan Hunian Di Lembaga Pemasyarakatan," Nommensen Journal of Legal Opinion 1, no. 01 (June 30, 2020): 27-37, www.ejournal.uhn.ac.id.

18 Joshua Gilbert Bawowo, Altje A Musa, and Toar K Palilingan, "Upaya Lembaga Pemasyarakatan Dalam Penanggulangan Penyalahgunaan Narkotika Oleh Narapidana Ditinjau Dari Undang-Undang Nomor 12 Tahun
} 
direction called the rehabilitation of a lawbreaker, the nature of the criminal imposition itself as an impact on violators of the rule of law or violation of the law is impossible to eliminate because it is not necessarily proven which system is more likely to be better at rehabilitating and repairing lawbreakers. In its development, there are still many who question the benefits of using imprisonment to solve crime problems because of its effectiveness.

The penalty for freedom of movement is also recognized as an appropriate sanction for certain crimes and certain offenses. ${ }^{19}$ The alternative for the short-term freedom of movement is assumed to be the total penalty for restricting the movement of fewer than six months. So the criminal deprivation of freedom of movement imposed on him, which is imposed for less than six months or six months and below, is a short-term crime of deprivation of freedom of movement. The existence of a short-term criminal deprivation of liberty raises various problems, such as the number of inmates living in prisons being out of balance with the number of inhabited capacities in prison buildings. ${ }^{20}$ So that the correctional institution becomes overcapacity which causes the implementation of punishment to be ineffective

The problem of overcapacity experienced by this correctional institution has been going on for a long time. ${ }^{21}$ Correctional institutions that have been used as institutions to foster prisoners to realize their mistakes and will not repeat their actions are no longer effective in realizing the goals of their punishment. Correctional institutions are used as crime schools. The density of inmates and the non-fulfillment of the rights of prisoners create new problems between prisoners. Inmates with narcotics cases who should be rehabilitated have a terrible impact on prisoners with theft cases. Inmates with theft cases who previously did not use narcotics made drug dealers because they could not meet their food needs due to the unavailability of food from prisons.

Lack of a sense of justice and certainty in applying criminal law and the ineffective implementation of the criminal justice system in Indonesia. The justice felt by the community's value of justice is felt to be lacking in balance and satisfaction for all parties. Justice must realize the conditions of truth in an ideal and balanced manner, but in practice, the law often gives decisions that are far from a sense of justice. Law enforcement that provides applicable laws and legal regulations is a significant factor in realizing effective law enforcement. The application of a just law needs to be supported by law enforcers to provide other efforts in imposing a prison sentence into a decision that has a more positive impact on the perpetrator following the crime caused. In realizing justice with a sense of security, it must be supported by community participation and supported by existing provisions and the behavior of law enforcers.

Looking for an alternative criminal imposition can help to reduce overcapacity on a penal basis. Where the crime of deprivation of liberty (prison punishment) is experiencing a crisis, government policies are budgeting for the construction of cell room facilities to the construction of new prisons to increase the capacity of prisoners as an effort to reduce overcapacity. ${ }^{22}$

\footnotetext{
1995 Tentang Pemasyarakatan," Lex Et Societatis VIII, no. 4 (October 20, 2020): 165-75, https://doi.org/10.35796/les.v8i4.30921.

${ }^{19}$ Muhammad Arif Sahlepi, "Reformasi Hukum Lembaga Pemasyarakatan Sebagai Sub Sistem Peradilan Pidana," Jurnal Hukum Kaidah: Media Komunikasi Dan Informasi Hukum Dan Masyarakat 17, no. 2 (March 14, 2018): 90-96, https://jurnal.uisu.ac.id/index.php/jhk/article/view/355/369.

${ }^{20}$ Muhammad Fauzar Rivaldy and Mety Rahmawati, "Konsep Sanksi Pidana Penjara Cicilan Sebagai Alternatif Pemenjaraan Baru Dalam Upaya Mengatasi Over Capacity/Kelebihan Kapasitas Di Dalam Lembaga Permasyarakatan," Jurnal Hukum Adigama 1, no. 1 (July 19, 2018): 611, https://doi.org/10.24912/adigama.v1i1.2159.

21 Ahmad Fajri, "Pidana Kerja Sosial Dalam Membatasi Kelebihan Penghuni Di Lembaga Pemasyarakatan," Jurnal Lex Renaissance 4, no. 1 (January 1, 2019): 46-64, https://doi.org/10.20885/jlr.vol4.iss1.art3.

${ }^{22}$ Samuel Arsheldon, Supriardoyo Simanjuntak, and Kornelius Benuf, "Strategi Antisipasi Over Kapasitas Lapas Suatu Refleksi Atas Kebijakan Pencegahan Penyebaran Covid-19," ADLIYA: Jurnal Hukum Dan Kemanusiaan 14, no. 1 (July 13, 2020): 1-26, https://doi.org/10.15575/adliya.v14i1.8553.
} 
However, these efforts are deemed less effective in constructing new building facilities, requiring a significant amount of time and budget, plus the number of new inmates, which will increase the overcapacity in prisons.

The Rajabasa prison has simplified the conditions for granting prisoners' rights, including providing conditional leave. Leave before release, parole, and employing prisoners with good behaviour to help prison staff get used to contributing to the new society. These activities have a practical impact on reducing overcrowding in prisons. ${ }^{23}$ However, many people do not understand that the community must work together to give confidence that prisoners who are nearing their release must be assisted to carry out social life properly following applicable norms.

The choice of social work punishment is also under the current international trend and not contradicting the values that exist in society. Theoretically, social work crimes can fulfil the intended purpose of punishment. Social work crime can protect in an integrated manner between community and individual protection as the purpose of punishment has been formulated. Efforts are being made to reduce excess capacity in prisons as an alternative crime; social work crimes will undoubtedly negate the harmful effects of crime education by criminals. Because correctional institutions often function as places for criminals to study, which will give birth to more professional criminals.

Social work crimes are felt to be very important to be developed into legal reform in Indonesia, which changes the paradigm of society and law enforcement officers which started with deprivation of freedom of movement and will to turn into criminal sanctions for deprivation of independence but does not focus on depriving a person of the right to freedom. Following the cultural values of the Indonesian people, which have the basic idea of Pancasila as the basis contained in the value of the fifth precept in the form of social justice for all Indonesian people, which means that the State has no right to punish and the State should protect all the blood of its citizens, even those who break the law.

Social work crime has an element of community protection because no real treatment action from the State is not under the nation's cultural values. During their sentence, the inmates are nurtured and guided in terms of their behavior and attitude. From the social work crime, the inmates do not try to do their wrong again because it is no longer a crime if they do. The court may impose a criminal deprivation of freedom of movement.

\section{Potential Alternative Criminals as Substitute for Imprisonment in Indonesian Criminal Law Regulations}

The renewal of alternative punishments to reduce overcapacity in correctional institutions, which it is felt that there should be clear rules and firmness in solving the problem of overcapacity and the ineffectiveness of coaching that occurs in prisons. Alternative criminal reform to realize the purpose of sentencing. Alternative criminal reforms to social work crimes are considered more effective in overcoming overcapacity in correctional institutions and can realize the goals of sentencing. ${ }^{24}$

The formulation policy of alternative criminals is by making various criminal regulations that create alternative criminal sanctions from criminal restrictions on mobile crimes, including a criminal model of supervision and a social work crime. This social work crime was made in the framework of a framework as another alternative offered from the short-term criminal deprivation of liberty. Therefore, to find out the implementation of the criminal deprivation of

${ }^{23}$ Interview with the Head of the Development Division for Class 1 Prison Inmates in Bandar Lampung, March 30, 2020.

${ }^{24}$ Fatkhur Rokhman, "Over Capasity as an Opportunity Fot the Directorate General of Correctors In Optimizing Revitalization," Walisongo Law Review (Walrev) 2, no. 2 (November 30, 2020): 221, https://doi.org/10.21580/walrev.2020.2.2.5325. 
liberty, especially the short-term criminal confiscation, in its implementation, it became a fundamental concept starting from the concept which was interpreted as the extent of the criminal social work has the opportunity to be implemented as an alternative to criminal.

Social work crime is considered adequate to be developed in the renewal of criminal law in Indonesia, which changes the paradigm of society regarding the treatment of lawbreakers, which begins with deprivation of freedom of movement and will which turns into quite promising sanctions which indeed raise the same as criminal sanctions for deprivation of liberty but do not refer to sanctions that deprive a person of independence. Criminal social work is very effective because it is based on work done to help a person or institution without getting paid. Social work crime has a meaning, namely the element of community protection. There are already existing criminal acts from the government guided by the Indonesian people's cultural values, namely making actions that have social values because they are carried out in a society that does not prioritize profit. During their sentence, the inmates are fostered and guided, informing their behavior and attitudes.

The crime of deprivation of liberty or imprisonment is a form of crime that has received criticism. Its effectiveness is doubtful in realizing the objectives of the punishment. The criminal system is an essential part of the criminal code of a nation because of that the criminal system reflects the socio-cultural values of the nation. In other words, how the State treats lawbreakers reflects how far the nation's civilization is. According to Ngadino, a society and a state without imprisonment is a form of threat from the main criminal offenses listed in the law, which are often imposed or given by law enforcement officers to violators of criminal acts to improve the attitudes and behavior of violators of the law even though the system of treating lawbreakers is heading towards rehabilitation. ${ }^{25}$ For violators of criminal acts, freedom of movement is given to provide benefits and provide an opportunity for inmates to improve themselves in the community and continue their functions in the community, eliminate the impact of stigma and labeling former inmates, avoid the privatization process or negative culture from prisons, costs cheaper and the use of State facilities or facilities can be reduced.

Social work crime as an alternative to a criminal is considered essential to be developed further to change the wrong paradigm regarding the treatment of law violators in Indonesia, which has so far been far from the values adopted by the Indonesian people. Based on the Indonesian State, the State wants justice based on nationalist justice that includes all people without exception. Social work crimes contain protection elements for the community because they can prevent law violators from the dangers of the latent impact of prison.

Solutions for overcapacity in correctional facilities to foster inmates include several institutional actions in the form of conditional and suspended sentences. Law enforcement officers maximize the use of alternative coaching to reduce the overcapacity of correctional institutions. Efforts to reduce overcapacity in prisons by reducing imprisonment and optimizing alternative punishments and restorative justice settlement models have the most significant impact on reducing overcapacity in prisons and impacting making changes to lawbreakers. That is the context of providing morals in the setting, determining whether the offense is considered an appropriate alternative course of action in a given situation. ${ }^{26}$

Based on this, it is necessary to reform the criminal law, which currently must also be followed by the concept of protection of Human Rights. Criminal law reforms must also include those related to criminal law enforcement, especially the prison system. Therefore, reform of criminal law in Indonesia should be carried out because it has become a reasonably urgent need.

\footnotetext{
${ }^{25}$ Interview with the Head of the Development Division for Class 1 Prison Inmates in Bandar Lampung, March 30, 2020.

${ }^{26}$ Georg Kessler and Jost Reinecke, "Dynamics of the Causes Of Crime: A Life-Course Application of Situational Action Theory for the Transition from Adolescence to Adulthood," Journal of Developmental and Life-Course Criminology, March 6, 2021, 1-24, https://doi.org/10.1007/s40865-021-00161-z.
} 
The Criminal Code or Kitab Undang-Undang Hukum Pidana (KUHP) in Indonesia is a legacy from the Dutch colonial era, which in practice is no longer under the development of the pattern of life of Indonesian society today. In connection with efforts to reform Indonesia's criminal law to be more focused and integrated, social work crime has become one of the discourses regarding criminal alternatives to minor crimes already known in several countries. As one of the countries that are in the process of updating its criminal law, Indonesia can conduct an indepth study of social work crime because social work crime has become an alternative to criminal in various international countries.

Potential alternative punishments as imprisonment substitute to criminals based on the judge's belief can reduce overcapacity in correctional institutions. They can provide a lesson for lawbreakers and avoid novice lawbreakers from the harmful effects of imprisonment and society's negative stigma towards perpetrators lawbreakers serving time in prison. Alternative punishment is deemed to be following the purpose of punishment, although there are still few law enforcement officers who apply alternative punishment as another choice from imprisonment.

\section{Conclusion}

The formulation policy on alternative social work crimes is an effort to reduce overcapacity in correctional institutions, causing new problems and having a negative impact, especially on novice criminals. Social work crime provides an effort to create the goals of the punishment itself. Social work crime can be determined in Indonesia as one of the types of punishment in the future because it can be seen under the purpose of punishment. The social cooperation crime itself arises from criticism of imprisonment because of its adverse effects, as is happening now. The policy of formulating social work crimes in the future has been well formulated in the draft criminal law code. The suggestion from the author is that it is necessary to conduct a more indepth study together with experts to find the formulation and form of social work punishment that is proportional and appropriate per existing values to be applied in Indonesia. There is a need for socialization to the community about social work crime to better understand and understand the types of social work crimes.

\section{Bibliography}

\section{A. Books}

Lamintang, P.A.F. Hukum Penitensier Indonesia. Bandung: Armico, 1984. Priyatno, Dwijaya. Sistem Peradilan Pidana Penjara. Bandung: Rafika Aditya, 1996. Roeslan Saleh. Stelsel Pidana Indonesia. Jakarta: Aksara Baru, 1983. Sudarto. Kapita Selekta Hukum Pidana. Bandung: Alumni, 1986.

\section{B. Journals}

Alikhademi, Kiana, Emma Drobina, Diandra Prioleau, Brianna Richardson, Duncan Purves, and Juan E. Gilbert. "A Review of Predictive Policing from the Perspective of Fairness." Artificial Intelligence and Law, April 15, 2021, 1-17. https://doi.org/10.1007/s10506-02109286-4.

Angkasa, Angkasa. "Pidana Perampasan Kemerdekaan Mandiri Sebagai Jenis Pidana Alternatif Untuk Mengurangi Kelebihan Populasi (Overpolulation) Narapidana Di Lembaga Pemasyarakatan Dan Beban Pemerintah." Perspektif Hukum 20, no. 2 (September 12, 2020): 1-30. https://doi.org/10.30649/PHJ.V20I2.268.

Arsheldon, Samuel, Supriardoyo Simanjuntak, and Kornelius Benuf. "Strategi Antisipasi Over Kapasitas Lapas Suatu Refleksi Atas Kebijakan Pencegahan Penyebaran Covid-19.” 
ADLIYA: Jurnal Hukum Dan Kemanusiaan 14, no. 1 (July 13, 2020): 1-26. https://doi.org/10.15575/adliya.v14i1.8553.

Aryana, I Wayan Putu Sucana. "Efektivitas Pidana Penjara Dalam Membina Narapidana." DiH: Jurnal Ilmu Hukum 11, no. 21 (October 1, 2015): 39-44. https://doi.org/10.30996/dih.v11i21.446.

Ayal, Shahar. "Comments on 'the Law of Good People': Regulating Justified Dishonesty." Jerusalem Review of Legal Studies 22, no. 1 (December 1, 2020): 38-48. https://doi.org/10.1093/jrls/jlz013.

Esther, July, Bintang Me Naibaho, and Bintang Christine. "Mediasi Penal Dalam Penanganan Pelaku Tindak Pidana Sebagai Upaya Meminimalisir Kelebihan Hunian Di Lembaga Pemasyarakatan." Nommensen Journal of Legal Opinion 1, no. 01 (June 30, 2020): 2737. www.ejournal.uhn.ac.id.

Fajri, Ahmad. "Pidana Kerja Sosial Dalam Membatasi Kelebihan Penghuni Di Lembaga Pemasyarakatan." Jurnal Lex Renaissance 4, no. 1 (January 1, 2019): 46-64. https://doi.org/10.20885/jlr.vol4.iss1.art3.

Gilbert Bawowo, Joshua, Altje A Musa, and Toar K Palilingan. "Upaya Lembaga Pemasyarakatan Dalam Penanggulangan Penyalahgunaan Narkotika Oleh Narapidana Ditinjau Dari Undang-Undang Nomor 12 Tahun 1995 Tentang Pemasyarakatan." Lex Et Societatis VIII, no. 4 (October 20, 2020): 165-75. https://doi.org/10.35796/les.v8i4.30921.

Harefa, Safaruddin. "Kebijakan Kriminal Dalam Menanggulangi Kelebihan Kapasitas Lembaga Pemasyarakatan." Jurnal Yuridis 5, no. 2 (April 26, 2019): 294. https://doi.org/10.35586/.v5i2.773.

Hutabarat, Rugun Romaida. "Problematika Lembaga Pemasyarakatan Dalam Sistem Peradilan Terpadu." Jurnal Muara Ilmu Sosial, Humaniora, Dan Seni 1, no. 1 (May 10, 2017): 42. https://doi.org/10.24912/jmishumsen.v1i1.333.

Jati, Ilham Panunggal. "Implikasi Overcapacity Terhadap Lembaga Pemasyarakatan Di Indonesia." Cepalo 3, no. 2 (November 25, 2019): 77. https://doi.org/10.25041/cepalo.v3no2.1847.

Kessler, Georg, and Jost Reinecke. "Dynamics of the Causes Of Crime: A Life-Course Application of Situational Action Theory for the Transition from Adolescence to Adulthood." Journal of Developmental and Life-Course Criminology, March 6, 2021, 124. https://doi.org/10.1007/s40865-021-00161-z.

König, Pascal D, and Georg Wenzelburger. "When Politicization Stops Algorithms in Criminal Justice." The British Journal of Criminology 61, no. 3 (April 24, 2021): 832-51. https://doi.org/10.1093/bjc/azaa099.

Marbun, Rocky. "Konsep Diyat Sebagai Alternatif Pemidanaan Dalam Sistem Peradilan Pidana Untuk Mengatasi Fenomena Overcapacity Lembaga Pemasyarakatan.” Jurnal Hukum Dan Peradilan 6, no. 2 (July 31, 2017): 189. https://doi.org/10.25216/jhp.6.2.2017.189212.

Morrow, Weston J., Samuel G. Vickovic, and John A. Shjarback. "Motivation to Enter the Police Profession in the Post-Ferguson Era: An Exploratory Analysis of Procedural Justice." Criminal Justice Studies 34, no. 2 (2021): 135-55. https://doi.org/10.1080/1478601X.2020.1802591.

Mulyono, Galih Puji, and Barda Nawawi Arief. "Upaya Mengurangi Kepadatan Narapidana Dalam Lembaga Pemasyarakatan Di Indonesia." Law Reform 12, no. 1 (March 31, 2016): 1. https://doi.org/10.14710/lr.v12i1.15838.

Rivaldy, Muhammad Fauzar, and Mety Rahmawati. "Konsep Sanksi Pidana Penjara Cicilan Sebagai Alternatif Pemenjaraan Baru Dalam Upaya Mengatasi Over Capacity/Kelebihan Kapasitas Di Dalam Lembaga Permasyarakatan.” Jurnal Hukum Adigama 1, no. 1 (July 
19, 2018): 611. https://doi.org/10.24912/adigama.v1i1.2159.

Rokhman, Fatkhur. "Over Capasity as an Opportunity Fot the Directorate General of Correctors In Optimizing Revitalization." Walisongo Law Review (Walrev) 2, no. 2 (November 30, 2020): 221. https://doi.org/10.21580/walrev.2020.2.2.5325.

Sahlepi, Muhammad Arif. "Reformasi Hukum Lembaga Pemasyarakatan Sebagai Sub Sistem Peradilan Pidana." Jurnal Hukum Kaidah: Media Komunikasi Dan Informasi Hukum Dan Masyarakat 17, no. 2 (March 14, 2018): 90-96. https://jurnal.uisu.ac.id/index.php/jhk/article/view/355/369.

Usman, Usman, Bahder Johan Nasution, and Elizabeth Seregar. "Over Kapasitas Lembaga Pemasyarakatan Dalam Perespektif Kebijakan Hukum Pidana.” Wajah Hukum 4, no. 2 (October 19, 2020): 436-44. https://doi.org/10.33087/WJH.V4I2.256. 